\title{
PRAKTIK GEOWISATA KARANGSAMBUNG KEBUMEN: TINJAUAN PERSPEKTIF DUALITAS
}

\author{
Saptono Nugroho \\ Fakultas Pariwisata Universitas Udayana \\ Email: snug1976@gmail.com
}

\begin{abstract}
This research aims to understand the practice of geotourism in the area of Karangsambung Geological Nature Reserve, Central Java, with the perspective of duality as a tool of analysis. It was designed by qualitative methods, which was suitable to be applied to understand the dynamics of the uniqueness of human behavior that occurs naturally. The research finding are, the practice of geotourism in Karangsambung which is produced by the Center for Information and Terrestrial Conservation Indonesian Institute of Sciences (BIKK - LIPI) Karangsambung is still caught in the trap of dualism perspective. Geotourism practice which managed exclusively by BIKK - LIPI, it becomes a device for the continuity of symbolic violence against local people. It is a tourism-based violence. It needs the effort to create a new tourism structure that can accommodate the aspirations of the actors in Karangsambung, using panginyongan strategy to break the chain of dualism into duality perspective.
\end{abstract}

Keywords: geotourism practice, duality perspective, tourismbased violence, panginyongan strategy.

\section{Pendahuluan}

Wacana tentang geowisata merupakan salah satu bentuk kreasi pariwisata yang merupakan kontra wacana terhadap pariwisata massal. Hal ini dimungkinkan karena berdasarkan jenis atraksi yang ditawarkan, geowisata masuk dalam klasifikasi pariwisata minat khusus. Artinya, daya tarik wisata yang dikembangkan lebih banyak berbasis pada pemenuhan keinginan wisatawan secara spesifik (Dowling dan Newsome, 2006). Inilah yang menjadikan sifat massal yang melekat pada pariwisata modern terlucuti. Dengan tawaran atraksi yang terbatas, daya tarik wisata yang berbasis pada bentang alam ini melakukan proses seleksi alami untuk wisatawan yang datang, yaitu mereka yang tertarik dan memiliki minat pada bentang alam geologis dengan berbagai keunikan dan sejarahnya.

Sejak tahun 1854, Karangsambung, Kebumen, Jawa Tengah, telah dikenal sebagai wahana pembelajaran geologi. Geolog Belanda, Jung Huhn 
adalah salah satunya yang melakukan penelitian di kawasan ini. Kemudian dilanjutkan oleh peneliti Belanda lainnya sampai tahun 1933. Pasca itu, ilmu geologi mulai berkembang di Indonesia, ditandai dengan masifnya penelitipeneliti Indonesia melakukan penelitian di kawasan ini.

Praktik pariwisata yang berlangsung di Karangsambung memiliki keunikan tersendiri. Memiliki landscape geologi yang unik, Kawasan Cagar Alam Geologi Karangsambung (KCAGK) menjadi daya tarik bagi kawasan yang membentang di area seluas $20 \times 20 \mathrm{~km}^{2}$ dan terletak pada batas koordinat $109^{\circ} 35^{\prime}-109^{\circ} 41^{\prime} \mathrm{BT}$ dan $7^{\circ} 25^{\prime}-7^{\circ} 36^{\prime} \mathrm{LS}$ ini. Semua kekayaan geologi purba ini terbentang di Karangsambung, Kebumen. KCAGK ini dapat dianalogikan seperti kotak hitam (black box) bagi segala proses alam semesta. Wisatawan akan dapat menyaksikan bentuk batuan dasar pembentuk Pulau Jawa dan gugusan lava beku yang menempel di atas batuan sedimen, yang sebelumnya hanya dapat dilihat di pematang samudra di Hawai. Beberapa pakar geologi bahkan menyebut kawasan ini sebagai "Yellowstone National Park"-nya Indonesia. Fenomena ini merupakan hasil subduksi lempeng Indo-Australia di bawah lempeng Asia sekitar 120 juta tahun yang lalu (Kusumahbrata, 2008).

Desa Karangsambung yang merupakan titik pusat kawasan, terletak 19 km di sebelah Utara Kabupaten Kebumen, Provinsi Jawa Tengah. Berjarak sekitar $120 \mathrm{~km}$ dari Yogyakarta, dapat ditempuh menggunakan moda transportasi darat (Bus, Travel, Kereta Api) sekitar 3-4jam. Daya tarik wisata ini dapat dicapai melewati jalan beraspal berkelak-kelok yang relatif mulus, mengikuti alur Sungai Luk Ulo yang terletak di sisi Barat. Aktivitas wisata ilmiah di Karangsambung dikelola oleh UPT Balai Informasi dan Konservasi Kebumian Karangsambung - Lembaga Ilmu Pengetahuan Indonesia (BIKKLIPI). Berbagai fasilitas penunjang yang disediakan cukup memadai, yang terdiri dari gedung pertemuan, gedung perkantoran, tempat penginapan berpendingin, perpustakaan, workshop kerajinan batu mulia, areal parkir dan sarana pendukung lainnya, seperti mushola, toilet, dan kantin (Anshori, 2012).

Geowisata Karangsambung berfokus pada kegiatan untuk memahami proses-proses kebumian dari tiga dimensi waktu, baik proses yang terjadi pada jutaan tahun lalu, pada masa sekarang, dan proses yang kemungkinan akan terjadi pada era mendatang. Lewat aktivitas wisata ini, wisatawan akan memperoleh deskripsi aneka jenis batuan, proses terbentuknya bentang alam, serta dinamika bumi. Selain berfokus pada unsur pendidikan, juga menawarkan sisi petualangan. Aktivitas wisata ilmiah yang dikreasi BIKK LIPI ini meliputi ceramah ilmiah populer, diskusi, kunjungan lapangan ke berbagai lokasi penting, melihat koleksi batuan serta proses pembuatan batu mulia. Selain itu, wisatawan juga merasakan sensasi berburu puspa ragam batuan di sungai Luk Ulo. 


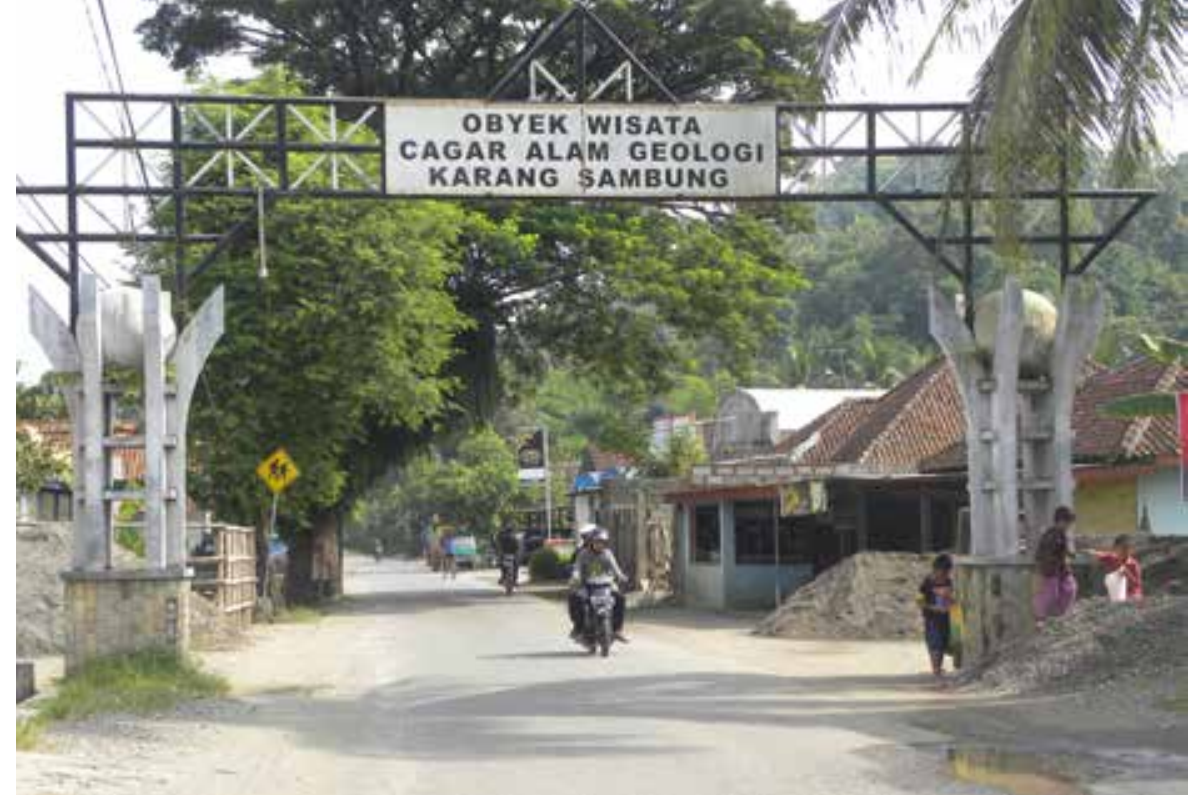

SAPTONO NUGROHO

Foto.1. Ilustrasi: Pintu masuk ke Objek Wisata Cagar Alam Geologi Karang Sambung. Gundukan pasir hasil penambangan di sisi kanan dan kiri jalan, menambah kesan kuat adanya tegangan antara kepentingan konservasi dan kepentingan ekonomi.

Akan tetapi, aktivitas pariwisata di Karangsambung menyimpan beberapa permasalahan. Pertama, walaupun telah berlangsung praktik pariwisata yang dinamakan sebagai geowisata Karangsambung, ternyata belum semua pemangku kepentingan yang berada dalam ranah ini memiliki sense of belonging, dalam arti praktik geowisata yang berlangsung masih elitis, dengan pihak Unit Pelaksana Teknis (UPT) Balai Informasi Konservasi Kebumian (BIKK) Karangsambung yang merupakan instansi kepanjangan tangan dari Lembaga Ilmu Pengetahuan Indonesia (LIPI) yang berperan sebagai produsernya. Terlihat masyarakat lokal acuh terhadap praktik geowisata yang berlangsung. Kedua, walaupun telah ditetapkan sebagai kawasan cagar alam geologi, terlihat adanya penambangan rakyat secara massif. Hal ini tentu merupakan praktik yang kontraproduktif bagi kelestarian alam Karangsambung.

Kedua, hal tersebut menjadi menarik untuk dikaji, guna menyingkap apa yang masih samar dalam praktik geowisata di Karangsambung, terkait dengan faktor yang mengondisikan munculnya fenomena apatisme masyarakat lokal dan maraknya aktivitas penambangan rakyat. Dapat dikatakan, para aktor atau agen (orang/pelaku konkret yang melakukan aktivitas sosial di ranah Karangsambung) masih berjalan sendiri-sendiri berdasarkan langgam kepentingannya masing-masing. Dalam konteks praktik pariwisata, hal ini mengindikasikan adanya perangkap dualisme. Dualisme diduga yang terjadi pada dua aras, yaitu di level interaksi sosial (antar aktor), dan di level interaksi aktor dengan alam fisik. 


\section{Rumusan Masalah}

Penelitian ini mencoba mengatasi perangkap dualisme yang terjadi di Karangsambung pada dua tingkatan. Pertama, dualisme yang terjadi di tingkatan relasi antara agensi/aktor dengan struktur yang sedang beroperasi di ranah.Kedua, dualisme antara manusia dengan lingkungan fisiknya.

Guna mencapai tujuan di atas, penelitian ini berusaha menyingkap praktik geowisata terjadi di Karangsambung, dengan menjawab pertanyaan penelitian yang diformulasikan menjadi tiga hal. Pertama, bagaimana praktik geowisata yang terjadi di Karangsambung? Kedua, bagaimana posisi para aktor atau agen (orang-orang yang kongkrit dalam arus kontinu tindakan dan peristiwa di dunia) dalam relasinya dengan lingkungan alamiah Karangsambung? Ketiga, apa implikasi relasi tersebut bagi keberlanjutan praktik pariwisata di Karangsambung? Dan, keempat, strategi apakah yang digunakan bagi praktik geowisata Karangsambung secara berkelanjutan?

\section{Metode Penelitian Dan Landasan Teori}

Metode yang digunakan dalam penelitian ini adalah metode kualitatif, mengambil lokasi di Desa Karangsambung Kabupaten Kebumen yang merupakan titik pusat dari Kawasan Cagar Alam Geologi Karangsambung (KCAGK). Pengumpulan data dilakukan dengan cara observasi lapangan, penelusuran literatur, dan wawancara dengan pengelola geowisata Karangsambung, penambang, masyarakat lokal dan pemerintah daerah. Data yang terkumpul secara deskriptif dipilah untuk kemudian direduksi sesuai kepentingan kajian. Analisis dilakukan secara kualitatif dengan intepretasi sebagai tiang pokok (Alwasilah, 2002).

Dalam penelitian ini ada tiga buah teori yang akan digunakan sebagai pisau analisis terhadap fenomena praktik geowisata di Karangsambung, yaitu: Teori Strukturasi dari Anthony Giddens, Teori Strukturalisme Genetis dari Pierre Bourdieu, dan Ekofenomenologi yang diinspirasi dari Merleau Ponty. Teori-teori ini dipilih karena memberikan perangkat konsep memadai, sederhana, dan memiliki kemampuan menjelaskan.

Ketiga teori ini, dalam konteks paradigma ilmu sosial kontemporer berada dalam naungan perspektif dualitas, sebagai wacana kritik terhadap perspektif dualisme yang sebelumnya kokoh sebagai wacana dominan (Ritzer, 2012). Dualitas agensi struktur merupakan merupakan kontra wacana terhadap perspektif dualisme yang lama mapan dalam maskapai ilmu sosial. Cara pandang dualitas coba mengoreksi dua paradigma yang saling bertentangan dan sulit didamaikan, yaitu antara fungsionalisme (yang berfokus pada kekuatan struktural yang berada di luar individu dan memiliki kemampuan memaksa); dan fenomenologi (bertitik tekan pada kemampuan aktor yang sadar dalam melakukan tindakan sosial). Perspektif dualitas menyintesakan antara determinasi struktur dan voluntaristik aktor. 
Giddens lewat teori strukturasinya, merupakan upayanya dalam memerangi cara pandang dualisme dalam ranah ilmu sosial. Menurutnya, ada kesalahan para pemikir dan analis sosial dalam menentukan fokus kajian, yang terjebak pada salah satu antara struktur sosial, atau tindakan sosial. Ia berpandangan, fokus kajian ilmu sosial bukan pada struktur atau tindakan, tetapi titik temu keduanya: praktik sosial (Giddens 1984). Giddens mengoreksi cara pandang dualisme dengan berupaya melakukan sintesa antara struktur dan tindakan sebagai relasi dialektis, dengan menambahkan konsepsinya tentang ruang dan waktu. Hubungan dualitas antara agen dan struktur dan sentralitas ruang dan waktu dimulai ketika terjadi dualitas (hubungan timbal-balik) antara agen dan struktur di dalam "praktik sosial (social practices) yang berulang dan terpola dalam ruang dan waktu”. Praktik sosial yang terjadi secara berulang-ulang (repetisi) dari agen-agen individu inilah yang mereproduksi struktur tersebut (Priyono, 2002).

Senada dengan pemikiran Giddens, Bourdieu juga mengembangkan gagasan tentang dualitas, dalam menelaah fenomena sosial yang berfokus pada praktik sosial. Konsep-konsep yang diperkenalkannya dalam membantu penyingkapan praktik sosial ini adalah: habitus (kebiasaankebiasaan; perantara antara aktor dengan realitas), modal (sumber daya yang diperjuangkan aktor untuk diakumulasi), dan ranah (ruang dinamis tempat berbagai potensi eksis). Praktik merupakan gagasan pemikiran Bourdieu yang merupakan vektor dari relasi habitus dan ranah sebagai produk sejarah. Di dalam ranah ada pertaruhan, kekuatan-kekuatan para aktor dengan modal yang dimilikinya. Modal merupakan sesuatu yang diperjuangkan, berupa konsentrasi dari kekuatan tertentu yang beroperasi dalam ranah (Takwin, dalam Harker dkk.ed. 2009).

Jika Giddens dan Boudieu berfokus pada praktik sosial dalam upayanya mengatasi dualisme, Ponty melalui ekofenomenologi berangkat dari gagasan dualitas tubuh dan dunia, sebuah filsafat tubuh (Hardiman, 2007). Filsafatnya berupaya mendamaikan dualisme antara aktor dengan alam. Tubuh dan dunia, menurut Merleau Ponty, berangkat dari konsep interweave (saling menjalin), yaitu dilihat sebagai dua entitas yang menyatu, saling tumpang tindih. Relasi diantara keduanya bukanlah relasi rangsangan dan reaksi, tetapi sebagai sesuatu yang saling menjalin dalam satu kesatuan. Konsep dualitas ini mendekonstruksi dualisme kesadaran yang ada dalam arus utama pemikiran sebelumnya. Upaya Ponty untuk lepas dari dualisme kesadaran-tubuh merupakan cara untuk membebaskan diri dari filsafat idealisme (idea/roh merupakan yang utama).

Carman (2008), menganalogikan filsafat Ponty sebagai daging, yang merupakan kesatuan tubuh dan dunia, sebuah dualitas. Pemikiran fenomenologi Ponty lepas dari dualisme idealisme (pengarusutamaan pada pemikiran/ide) dan empirisme (yang melulu berfokus pada pengalaman 
inderawi). Menurutnya, dengan menggunakan tubuh sebagai instalasi dalam kegiatan penafsiran fenomena kongkret yang dialami manusia, akan membawa pada relasi timbal balik (intersubyektif) antara manusia dengan alam, dan memupus relasi subyek-obyek kaum antroposentrisme cartesian. Perangkat rasio diganti dengan instalasi tubuh, yang memiliki kemampuan empati dalam berelasi dengan totalitas dunia yang dialami (Saraswati, 2013).

Teori Strukturasi Giddens digunakan untuk menganalisis geowisata sebagai proses terciptanya struktur sosial, yang memandu praktik pariwisata oleh para aktor secara berulang dan terpola di Karangsambung dibawah naungan sistem sosial yang bernama BIKK-LIPI Karangsambung. Teori Strukturalisme Genetis Bourdieu memberikan tilikan tentang identifikasi dan posisi antar aktor di dalam ranah pariwisata Karangsambung, terkait dengan dimensi modal yang diakumulasi, dan jenis habitus yang dimiliki. Sedangkan teori ekofenomenologi memberi pemahaman tentang proses interaksi antara manusia dengan lingkungannya, baik alam sosial maupun alam fisik. Dalam penelitian ini, ketiga teori tersebut digunakan untuk menjelaskan fenomena dualism trap yang terjadi di ranah pariwisata Karangsambung, sekaligus sebagai pemandu guna mencari jalan keluar dari jebakan tersebut.

\section{Praktik Geowisata Karangsambung}

Hasil penelitian menunjukkan, istilah geowisata di Karangsambung memiliki dua makna, yaitu: pertama, sebagai aktivitas wisata, dan, kedua, sebagai sebuah strukturasi, yang keduanya diproduksi oleh Balai Informasi dan Konservasi Kebumian Lembaga Ilmu Pengetahuan Indonesia (BIKKLIPI) Karangsambung. Pemaknaan pertama, yaitu geowisata sebagai sebuah aktivitas wisata yang diselenggarakan oleh BIKK-LIPI Karangsambung merupakan makna yang dimiliki oleh masyarakat secara umum (awam). Dalam istilah fenomenologi, merupakan makna pra-reflektif (spontan), yang belum direduksi atau dibingkai/ditafsir secara akademis. Sedangkan pemaknaan kedua, geowisata sebagai strukturasi, lebih bersifat analisis dan reduktif, guna kepentingan akademis, terkait dengan proses terbentuknya dan terselenggaranya geowisata beserta implikasi yang ditimbulkannya.

Geowisata sebagai fenomena empiris di Karangsambung, dapat dikonsepsikan sebagai praktik sosial. Artinya, geowisata merupakan aktivitas sosial yang berlangsung dalam ruang dan waktu Karangsambung yang dilakukan oleh aktor/pelaku konkret, dalam rangka memperjuangkan sumber daya pariwisata.

\subsection{Geowisata sebagai Aktivitas Wisata}

Sebagai aktivitas wisata, geowisata difasilitasi oleh pihak BIKK LIPI. Kegiatan initelah dimulai secara formal pasca ditetapkannya Karangsambung sebagai Kawasan Cagar Alam Geologi Karangsambung (KCAGK) berdasarkan 
Surat Keputusan Menteri Energi dan Sumber Daya Mineral Republik Indonesia Nomor: $2817 \mathrm{~K} / 40 / \mathrm{MEM} / 2006$, yang peresmiannya dilakukan oleh Presiden Susilo Bambang Yudhoyono pada tanggal 14 November 2006. Aktivitas geowisata Karangsambung sampai saat ini masih dikelola secara eksklusif oleh Unit Pelaksana Teknis (UPT) Balai Informasi dan Konservasi Kebumian Karangsambung - LIPI. Dalam operasinya, mereka memaknai praktik wisata ini sebagai wisata minat khusus (Ansori, 2012).

Wisata minat khusus yang mereka kelola dirancang secara berkelompok 20 sampai dengan 100 orang tiap berkunjung. Metode yang diaplikasikan berupa pengenalan mengenai kebumian secara in door (di dalam kelas) dan out door (di luar kelas). Sosialisasi informasi ilmu kebumian mulai dimasifkan beberapa tahun belakangan ini. Sosialisasi mengenai fenomena geologi di daerah Karangsambung serta keberadaan kampus Karangsambung digencarkan secara spesifik ke sekolah-sekolah di seantero Jawa Tengah. Upaya ini cukup efektif, terlihat dengan banyaknya pelajar mulai level TK hingga SMU yang mengunjungi Karangsambung. Mereka datang dari Kebumen, Gombong, Cilacap, Purwokerto, Wonosobo, Purworejo, Magelang, Yogyakarta dan Semarang. Menurut Peneliti Senior BIKK-LIPI Karangsambung Chusni Anshori, jumlah kunjungan wisatawan rata-rata pertahun mencapai sepuluh ribu wisatawan.

Kegiatan Studi Ilmu Kebumian antara lain dengan menyaksikan film kebumian, menikmati presentasi populer kawasan geologi Karangsambung, melihat koleksi berbagai batuan di museum, mengunjungi bengkel cinderamata, dan ekskursi lapangan di sekitar kampus dan sungai Luk Ulo. Aktivitas wisata minat khusus ini umumnya dilakukan ketika mengisi liburan sekolah, study tour, atau ekskursi lapangan untuk mata pelajaran geografi.

Adapun materi yang dirancang: pengetahuan umum sumberdaya bumi dan bencana kebumian serta Geologi Karangsambung, observasi gedung museum peraga batuan, observasi lingkungan kampus LIPI Karangsambung, dan kunjungan bengkel kerajinan batu mulia. Selain itu diberikan pula fasilitas berupa presentasi ilmiah populer dan pembimbing lapangan. Ada pula fasilitas lainnya, yaitu: asrama dan guest house, aula, dan hostspot.

\subsection{Geowisata sebagai Strukturasi}

Meminjam tilikan Giddens tentang berlangsungnya proses strukturasi, aktivitas berulang dan rutin serta berpola yang dilakukan aktor atau kelompok akan menghasilkan apa yang disebut struktur. Dalam konteks ini, geowisata di Karangsambung memungkinkan terciptanya sebuah struktur pariwisata. Struktur menurut Giddens (Priyono, 2002) adalah:

...praktik sosial yang berulang dan terpola dalam ruang dan waktu, praktik sosial yang berulang-ulang (repetisi) dari agen-agen individu yang mereproduksi struktur tersebut. 


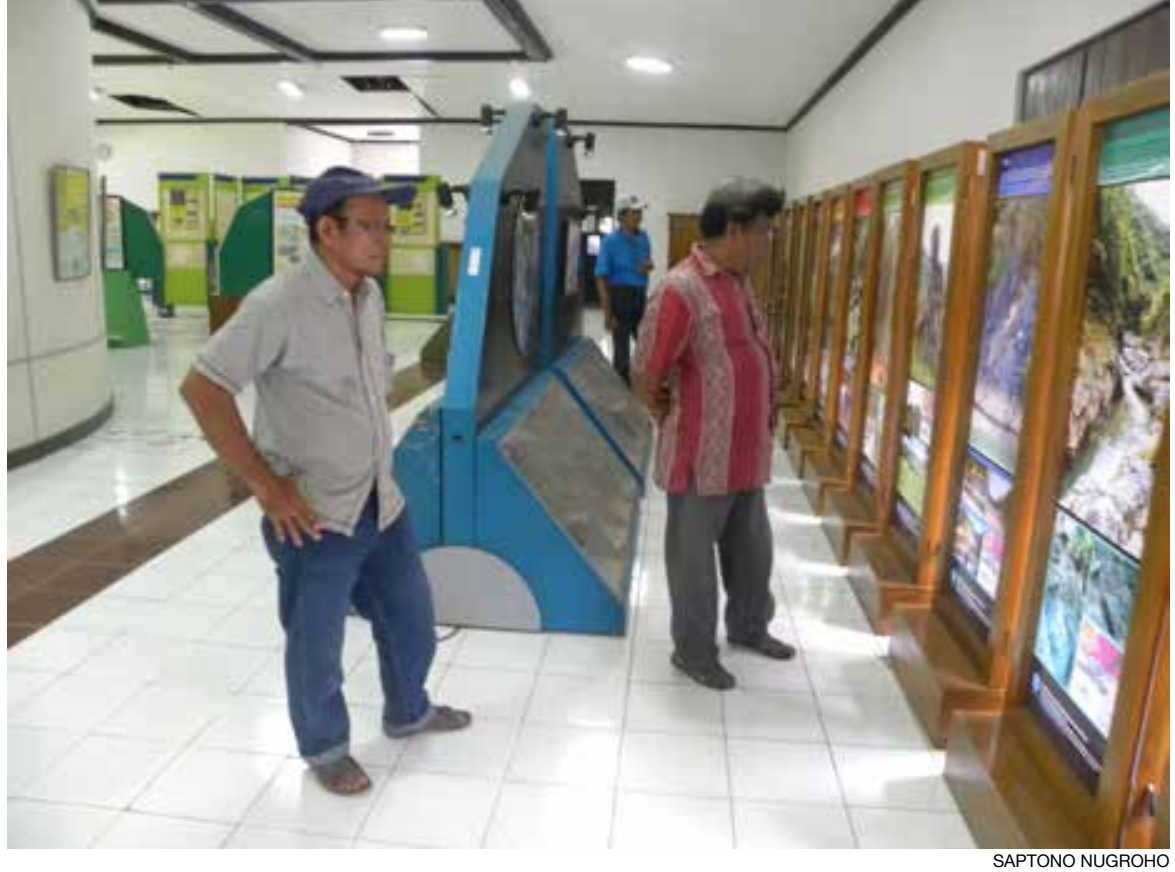

Foto 2. Ilustrasi: Salah satu aktivitas wisatawan: menyaksikan alat peraga berupa poster di Museum Geologi Karangsambung.

Artinya, aktivitas geowisata karena dilakukan secara berulang dan terpola (menyangkut antara lain: tata tertib, route yang ditempuh, biaya yang harus dibayar) dalam lokasi dan waktu yang relatif sama, dilakukan oleh agen-agen individu BIKK LIPI dan wisatawan, maka praktik geowisata menjelma menjadi praktik yang berulang dan berpola, yang pada akhirnya menciptakan struktur pariwisata dalam ranah Karangsambung.

Tabel 1. Skemata Strukturasi Pariwisata di Karangsambung

\begin{tabular}{lll}
\hline \multicolumn{1}{c}{ Struktur } & \multicolumn{1}{c}{ Sistem Sosial } & \multicolumn{1}{c}{ Praktik Sosial } \\
\hline - S (hak pengelolaan)-D-L & B BIKK Karangsam- & - Menyaksikan film kebumian. \\
- D (tingkatan garis otori- & bung & - Menikmati presentasi populer \\
sasi)- S-L & & kawasan geologi Karangsam- \\
- D (akumulasi keuntun- & bung. \\
gan ekonomi)-S-L & - Melihat koleksi berbagai batuan \\
- L (peraturan-peratur- & di Museum. \\
an)-D-S & - Mengunjungi bengkel cindera- \\
& mata. \\
& - Ekskursi lapangan di sekitar \\
& kampus dan sungai Luk Ulo.
\end{tabular}

Sumber: Analisis data, 2014

Keterangan: $\mathrm{S}$ = Signifikansi, D = Dominasi (atas orang atau barang), L = Legitimasi.

Skemata di atas menjelaskan proses strukturasi yang terjadi di Karangsambung. Tabel tersebut bisa dibaca dari kanan ke kiri (praktik sosial - sistem sosial - struktur sosial).

Aktivitas yang dilakukan wisatawan seperti menyaksikan film kebumian, 
menikmati presentasi populer kawasan geologi Karangsambung, melihat koleksi berbagai batuan di Museum, mengunjungi bengkel cinderamata, ekskursi lapangan di sekitar kampus dan sungai Luk Ulo, merupakan fenomena empiris yang ada di KCAGK. Aktivitas ini tidak terjadi secara insidental, hanya satu atau dua kali saja lalu menghilang tidak terjadi lagi. Kegiatan ini berlangsung teratur, terpola, dan sistematis. Teratur artinya relatif rutin, dalam periode waktu tertentu dan di lokasi kongkret. Terpola berarti aktivitas yang dilakukan dirancang dengan format/desain tertentu, dan sistematis adalah kegiatan tersebut difasilitasi oleh pihak tertentu dan berdasarkan aturan tertentu pula.

Aktivitas geowisata Karangsambung (kolom paling kanan) merupakan praktik sosial, dilakukan secara berulang-teratur-berpola karena difasilitasi oleh BIKK LIPI. Yang menjamin aktivitas wisata yang disebutkan di atas dapat berlangsung sebagai proses simultan karena terwadahi oleh sistem (geowisata yang dikreasi BIKK-LIPI). Akan tetapi proses ini tidak mungkin berlangsung hanya melewati tahap ini saja. Pada kolom pertama jika skemata pada tabel di atas dibaca dari kiri, terdapat struktur yang merupakan panduan bagi berjalannya proses geowisata sebagai praktik pariwisata, yang tentu saja merupakan sebuah praktik sosial.

Skemata aturan yang merupakan struktur tersebut terdiri dari $\mathrm{S}$ ( signifikansi = penandaan, misalnya = hak pengelolaan KCAGK), D [dominasi, yang terdiri dari dua bentuk: dominasi atas orang (politik), misalnya= pengaturan kegiatan wisatawan, dan dominasi atas barang (ekonomi), misalnya = penentuan harga tiket], L [legitimasi = seperangkat aturan yang legitimit, misalnya = standar operasional prosedur (SOP) geowisata] Skemata struktur ini bersifat abstrak, dan menjadi panduan yang dipatuhi oleh aktor (BIKK-LIPI, wisatawan,) dalam ranah karena proses aktivitas (praktik geowisata) berlangsung terus menerus dan menjadi rutin sehingga pada akhirnya menjadi praktik yang berlangsung secara otomatis, refleks dan tidak dipikirkan lagi.

Indikator ketika suatu struktur terbangun dan menjadi mapan adalah ketika agen-agen individu yang berada dalam ranah melakukan aktivitas di dalam ranah secara otomatis, tanpa perlu dipikirkan lagi. Dalam istilah Giddens disebut sebagai kesadaran praktis, dan dalam kosakata Bourdieu disebut habitus. Kedua konsep ini, baik kesadaran praktis maupun habitus, merupakan khas perspektif dualitas agensi-struktur. Perspektif ini merupakan pengatasan dari kebuntuan perspektif dualisme yang lama melanda dalam ilmu sosial (ataukah individu-ataukah struktur yang utama, tidak mungkin keduanya).

Dengan basis atraksi yang ditawarkan kepada wisatawan berupa bentang alam yang memiliki nilai ilmiah geologis, wisata ini dikonstruksi sebagai wisata minat khusus. Hal ini menimbulkan demarkasi yang tegas karena 
label khusus yang disematkan. Maknanya adalah karakter wisatawan yang datang atau diharapkan datang adalah mereka yang memiliki minat terhadap lanskap geologi beserta informasi ilmiah kebumian (walaupun dikemas secara populer, bukan dengan bahasa rigorous sains). Pertanyaannya adalah, siapa yang memiliki kompetensi memfasilitasi minat wisatawan yang seperti itu? Jawabnya mudah: tentu saja pihak BIKK LIPI.

Agen di luar mereka, yaitu masyarakat lokal, tidak memiliki jenis kesadaran ini, sehingga skemata pariwisata tidak ada dalam referensi pemaknaan masyarakat lokal. Hal inilah yang menjadikan aktivitas geowisata yang berlangsung di Karangsambung menjadi ekslusif, tidak terjadi interaksi dengan masyarakat lokal. Masyarakat lokal teraleniasi dari pariwisata yang ada di wilayahnya. Artinya, dalam konteks struktur pariwisata yang terbangun, agensinya hanya BIKK LIPI. Dengan kata lain, habitus dan kesadaran praktis pariwisata hanya eksklusif dimiliki aktoraktor BIKK LIPI (perangkat staff dan karyawannya).

\subsection{Posisi Aktor dalam Relasinya dengan Alam}

Berikutnya, terkait posisi aktor dalam relasinya dengan alam KCAGK, berhasil diidentifikasi dua kategori aktor, yaitu: aktor umum (terdiri dari BIKK-LIPI, masyarakat lokal, penambang, dan pemerintah), dan aktor utama, yaitu BIKK-LIPI dan penambang (terdiri dari penambang mesin dan penambang manual). Posisi mereka ditentukan dari penafsiran mereka terhadap alam.

\subsubsection{Aktor Umum}

Terdapat empat agen/ aktor umum terkait dengan konteks relasinya dengan alam berdasarkan tafsir dan aktivitas yang dilakukan, seperti dituangkan dalam tabel berikut:

Tabel 2. Skemata Posisi para Aktor secara Umum di Ranah Karangsambung.

\begin{tabular}{|c|c|c|c|c|c|}
\hline \multirow{2}{*}{ Persepsi } & \multirow{2}{*}{ BIKK-LIPI } & \multirow{2}{*}{$\begin{array}{l}\text { Masyarakat } \\
\text { Lokal }\end{array}$} & \multicolumn{2}{|c|}{ Penambang } & \multirow{2}{*}{ Pemerintah } \\
\hline & & & Manual & Mesin & \\
\hline Tafsir & $\begin{array}{l}\text { - Nilai Ilmiah } \\
\text { Tinggi } \\
\text { - Tugas Pokok } \\
\text { dan Fungsi }\end{array}$ & Ruang hidup & $\begin{array}{l}\text { Manfaat ekon- } \\
\text { omis }\end{array}$ & $\begin{array}{l}\text { Manfaat ekon- } \\
\text { omis }\end{array}$ & $\begin{array}{c}\text { Wilayah } \\
\text { administrasi }\end{array}$ \\
\hline Aktivitas & $\begin{array}{l}\text { - Riset } \\
\text { - Konservasi } \\
\text { - Geowisata }\end{array}$ & $\begin{array}{c}\text { Pemanfaatan } \\
\text { sungai (MCK) }\end{array}$ & $\begin{array}{l}\text { Menambang } \\
\text { skala kecil } \\
\text { (manual) }\end{array}$ & $\begin{array}{l}\text { Menambang } \\
\text { skala besar } \\
\text { (mesin) }\end{array}$ & $\begin{array}{l}\text { Penegakkan } \\
\text { aturan }\end{array}$ \\
\hline
\end{tabular}

Sumber: Analisis data, 2014

Identifikasi terhadap aktor yang ada di ranah pariwisata Karangsambung akan menjadi dasar bagi analisis terhadap modal yang diperjuangkan dan komposisinya yang ada ditiap aktor atau kelas/kelompok. 


\subsubsection{Relasi Aktor Utama dengan Alam}

Berdasarkan analisa terhadap observasi dan wawancara yang dilakukan, terdapat beberapa relasi yang terbangun antara aktor dan alam di KCAGK, dengan menggunakan perspektif ekofenomenologi. BIKK Karangsambung dan Penambang merupakan dua aktor utama yang akan dikaji.

\section{a. BIKK Karangsambung dengan KCAGK.}

Sebagai pihak yang memiliki modal simbolis, aktor yang berhimpun di kelas ini memiliki cara pandang khas terhadap KCAGK. Tafsir geologis ilmiah terhadap ranah tentu saja berada dalam kuasa mereka sepenuhnya. Operasi kuasa yang dipraktekkan dengan melakukan aktivitas akademis: mulai dari penelitian, ceramah ilmiah, sampai mengkreasi geowisata sebagai satu-satunya praktik pariwisata "resmi" dalam kawasan.

Akan tetapi, dalam konteks relasi dengan alam, masih terdapat cara pandang dualisme. Jajaran BIKK menginginkan alam tetap lestari, utuh, dan tidak rusak. Cara pandang ekosentrisme dapat disematkan, ketika bereaksi terhadap aktivitas penambangan yang dilakukan sebagian warga:

"Pernah dalam suatu kegiatan ekskursi ke lapangan, saya berjumpa dengan warga yang melakukan aktivitas penambangan. Sengaja saya ajak rombongan yang saya antar untuk melewati route yang melewati kegiatan mereka. Tampak sekali mereka kikuk dan menghentikan aktivitasnya.” (Wawancara dengan Defry Hastria, Kepala Seksi Pengembangan dan Konservasi Karangsambung LIPI, 2014).

Tindakan tersebut jelas merupakan representasi dari ekspresi ketidaksukaan dan "penghukuman" bagi penambangan yang dilakukan warga. Dalam bahasa Bourdieu terjadi kekerasan simbolik. Aroma ekosentrisme tampak kental dalam konteks ini.

Apa yang dilakukan BIKK sejatinya sangatlah wajar, jika ditilik dari latar belakang (trajektori) mereka berada dalam ranah, yaitu sebagai aparatus negara yang memiliki tugas pokok dan fungsi tertentu. Dan, selain itu, diluar apa yang dimandatkan secara legal formal tersebut, latar belakang disiplin keilmuan juga berpengaruh besar terhadap cara pandang terhadap alam secara ekosentris ini.

b. Relasi Penambang dengan KCAGK.

Ada dua katagori penambang yang melakukan eksploitasi penambangan di KCAGK, yaitu penambang mesin dan manual. Keduanya memiliki cara pandang yang khas dalam konteks relasinya dengan alam. Ternyata perangkat/instrumen yang digunakan mereka dalam melakukan eksploitasi pasir dan batuan merepresentasikan sikap mereka terhadap alam.

Penambang mesin merupakan kelompok yang terorganisir, dalam arti mereka melakukan aktivitas secara berkelompok di bawah pengawasan seorang mandor. Mandor ini yang melakukan transaksi dengan pihak 


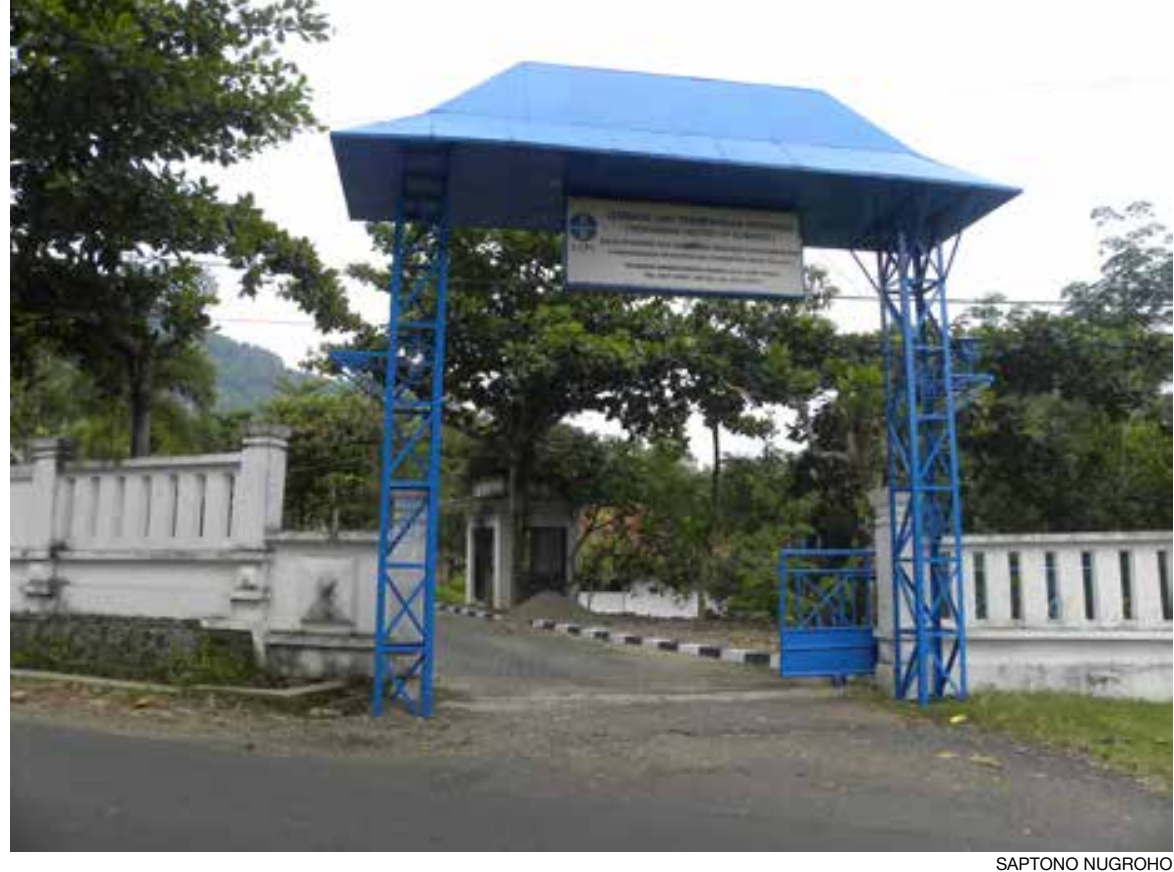

Foto 3. Ilustrasi: Kantor Balai Informasi dan Konservasi Kebumian - Lembaga Ilmu Pengetahuan Indonesia (BIKK-LIPI) Karangsambung.

pembeli, umumnya diwakili sopir truk pengangkut pasir yang merupakan orang yang mewakili pihak pembeli. Mandor ini yang mencatat jumlah pasir yang dimuat truk, dan sekaligus menerima pembayarannya. Uang yang diperoleh akan disetor kepada pemilik mesin sedot yang disebut warga sebagai juragane (bos).

Kelompok ini tentu saja representasi sempurna dari kaum antroposentrime, dengan relasi subyek-obyek yang dikonstruksinya dalam konteks relasi dengan alam. Aktivitas penambangan dengan menggunakan mesin (sedot dan alat berat) sangat jelas berangkat dari cara pandang dualisme tersebut. Basis rasionalitasnya sangatlah instrumental, dengan motif mengakumulasi modal ekonomi. Dengan terakumulasinya jenis modal tersebut, sebutan juragane tersemat untuk mereka.

Menariknya, berdasarkan analisa yang dilakukan terhadap kelompok penambang manual, mereka memiliki relasi yang unik dengan alam. Instalasi yang digunakan dalam melakukan relasi dengan alam adalah tubuh. Instrumen rasio yang melekat pada kelompok aktor lainnya (BIKK dan penambang mesin) dalam relasinya dengan alam, bisa dikatakan tidak berlaku bagi penambang manual ini. Berikut statement salah seorang penambang ketika diminta menceritakan proses mendapatkan bahan tambang:

"Kami mulai melakukan kerja ketika tengah malam, berjalan menyusuri sungai guna mendapatkan lokasi penggalian terbaik untuk besok pagi. Kami sangat bersyukur jika sejak sore hari turun hujan, karena berarti jumlah pasir di sungai akan berlimpah. Cara kami mengira di mana lokasi pasir terkumpul 
Masyarakat lokal mempunyai sebutan tersendiri bagi pihak BIKK-LIPI yaitu "kampus". Sebutan ini tentunya bukan tanpa sebab. Fakta bahwa banyak kalangan geolog melakukan riset, di semua strata pendidikan, menjadikan sebutan tersebut muncul. Asosiasi masyarakat terhadap BIKKLIPI adalah kumpulan orang pintar, berpendidikan tinggi, dan penjaga alam Karangsambung menjadikan masyarakat minder.

Ketika yang terjadi relasi seperti ini, akan sangat sulit bagi dipraktikkannya pariwisata yang dianggap dapat menjadi solusi bagi titik temu antara kepentingan ilmiah dengan kepentingan ekonomi di Karangsambung. Dalam bahasa strukturasi: belum ada ranah pariwisata bersama di Karangsambung.

\subsubsection{Mata Rantai Dualisme dalam Ranah}

Struktur pariwisata yang ada di KCAGK masih terjebak dalam perangkap dualisme. Dualisme yang terjadi berada di aras sosial antar aktor dan di tingkatan relasi yang dibangun antara manusia dengan alam. Praktik geowisata yang dikelola BIKK secara eksklusif justru menjadi sarana bagi berlangsungnya kekerasan simbolik terhadap warga. Aktivitas wisata yang berlangsung eksklusif, bagaikan berada dalam akuarium, menjadi tontonan bagi masyarakat lokal Karangsambung. Masyarakat menganggap aktivitas geowisata hanya bisa difasilitasi oleh "kampus", sekumpulan orang pintar dan terpelajar, yang memiliki pengetahuan ilmiah tentang lanskap alam Karangsambung. Mereka hanya memiliki istilah-istilah lokal terhadap lanskap alam tempat mereka dilahirkan dan dibesarkan. Dominasi tafsir ilmiah terhadap tafsir lokal terhadap lanskap alam Karangsambung inilah yang memunculkan fenomena kekerasan simbolik itu. Masyarakat menganggap apa yang dilakukan BIKK-LIPI sebagai hal yang benar dan wajar, sehingga dapat dikatakan, kekerasan simbolik beroperasi dengan sangat halus, tersamar, sehingga mereka yang terdominasi tidak merasa tertindas.

Dalam konteks relasi para aktor dengan alamnya, secara general bisa dikatakan masih terjadi hubungan saling menguasai, dominatif, yang membelenggu dan menjebak pada relasi subyek-obyek.

Tabel 3. Dualisme dan Dualitas Aktor di Ranah Karangsambung

\begin{tabular}{ccc}
\hline \multirow{2}{*}{ BIKK-LIPI } & \multicolumn{2}{c}{ Penambang } \\
\cline { 2 - 3 } & Mesin & Manual \\
\hline Dualisme & Dualisme & Dualitas \\
Ekosentrisme & Antroposentrisme & Ekofenomenologis
\end{tabular}

Sumber: Analisis data, 2014

BIKK masih cenderung berada di menara gading, belum mau berbaur langsung dengan warga. Dalam konteks tradisi yang berlaku di 
Karangsambung, BIKK belum masuk menjadi bagian dari panginyongan (orang kita), sehingga operasi praktek cablaka (terus terang, terbuka apa adanya) belum terjadi. Di antara mereka masih saling me-liyan-kan, belum terbangun in group feeling. Padahal BIKK bisa menangkap peluang untuk memecah kebuntuan dengan memanfaatkan adanya perpecahan di kalangan warga yang berbeda sikap terhadap aktivitas penambangan dengan menggunakan mesin. Hal ini bisa menjadi peluang untuk membangun isu bersama bagi penghentian operasi penambangan mesin.

\subsubsection{Kekerasan Berbasis Pariwisata}

Telah disinggung sebelumnya, praktik geowisata yang dikreasi BIKK-LIPI cenderung memproduksi apa yang disebut Bourdieu sebagai kekerasan simbolik. Beroperasi dengan sangat halus, menjadikan mereka yang didominasi gagal mengidentifikasinya. Dalam ranah pariwisata Karangsambung, kemampuan mendominasi dimiliki oleh aktor yang relatif memiliki modal lebih banyak, yang selanjutnya memiliki kapasitas dalam menentukan mana yang boleh dan tidak, benar dan salah dalam praktik pariwisata. Berikut coba diikhtisarkan kekerasan simbolik yang berlangsung di ranah Karangsambung:

Tabel 4. Skemata Implikasi Relasi antar Aktor dan antara Aktor dengan Alam dalam Ranah Karangsambung.

\begin{tabular}{llll}
\multirow{2}{*}{ Komponen } & \multirow{2}{*}{ BIKK-LIPI } & \multicolumn{2}{c}{ PENAMBANG } \\
\cline { 3 - 4 } HABITUS & Ekosentris & Antroposentris & \multicolumn{1}{c}{ Ekofenomenologis } \\
MODAL & $\begin{array}{l}\text { Simbolik, Sosial, } \\
\text { ekonomi }\end{array}$ & Ekonomi, Budaya & Budaya \\
RANAH & Ilmiah & Ekonomi & Kearifan lokal \\
PRAKTIK & Geowisata & $\begin{array}{l}\text { Penambangan skala } \\
\text { besar }\end{array}$ & \\
\hline Efek & & & \\
\hline
\end{tabular}

Sumber: Analisis data, 2014.

Apa yang tertuang pada tabel 4, jika menggunakan strukturalisme genetis Bourdieu sebagai pisau analisis, dapat diperoleh pemahaman bahwa BIKK LIPI memiliki modal yang relatif lengkap yaitu modal simbolik, ekonomi, dan sosial. Dengan modal simbolik dalam genggaman, posisi BIKK LIPI cenderung kuat, mengingat sifat dari modal simbolik ini dapat dengan lincah dipertukarkan dengan dua bentuk modal lainnya, yaitu modal ekonomi dan modal budaya. Seperti yang telah dipaparkan sebelumnya, modal simbolik memberi kuasa bagi aktor untuk memberi penafsiran resmi bagi wacana yang bergulir dalam ranah. Dalam konteks tertentu pemilik modal ini akan didapuk menjadi juru bicara resmi dari kelompok hegemonik dalam ranah. 
Demikianlah, BIKK LIPI memiliki kuasa untuk memberi "pemaknaan resmi” ranah Karangsambung sebagai situs geologi. Kekuasaan tersebut ditopang oleh perangkat aturan legal formal berupa SK Menteri ESDM yang menyatakan kawasan ini sebagai kawasan cagar alam geologi dengan nama resmi KCAGK ditambah topangan politis ketika pejabat formal negara setingkat presiden melegalisasinya dalam suatu peresmian berpuncak pada penandatangan prasasti yang "dihadiahkan" untuk BIKK LIPI. Lengkaplah sudah legitimasi yang dipunyai BIKK LIPI sebagai aparatus negara yang hadir dalam ranah.

Tetapi fakta di ranah Karangsambung menunjukkan, karena belum terdapat sebuah struktur yang "mengikat" para aktor dalam satu ranah, aktivitas yang dikreasi oleh mereka berangkat dari habitus yang relatif berbeda. BIKK-LIPI dengan habitus ekosentrisnya, penambang mesin dengan habitus antroposentris, sedangkan penambang manual dengan habitus ekofenomenologisnya. Sehingga, dalam bingkai strukturasi Giddens, ada dua ranah yang distruktur dan menstruktur aktor, yaitu ranah ilmiah dan ranah ekonomi. Hal ini berimplikasi terhadap kreasi aktivitas yang dilakukan aktor: geowisata oleh BIKK-LIPI, penambangan skala besar oleh penambang mesin, dan ngirig oleh penambang manual.

Yang menjadi temuan kunci adalah munculnya efek kekerasan simbolik dalam skemata tersebut. Tampak bahwa arus kekerasan simbolik pada tabel di atas mengalir dari kiri ke kanan. Artinya, aktor yang memiliki modal relatif lengkap secara kuantitas (komposisi jumlah) maupun kualitas (kemampuan dalam maksimalisasinya) cenderung memiliki efek kekerasan simbolik bagi aktor yang relatif lemah dalam mengakumulasi modal yang disediakan ranah. Penambang manual adalah aktor jenis ini sehingga posisinya dalam ranah lemah dan mendapatkan efek kekerasan simbolik dari kedua aktor yang lainnya.

Geowisata karena dikreasi oleh aktor yang memiliki modal lengkap dalam ranah (BIKK-LIPI) membawa efek kekerasan simbolik ketika dipraktikkan dalam ranah Karangsambung. Pihak BIKK-LIPI sering menggunakannya untuk menunjukkan kepada penambang bahwa aktivitas geowisatalah yang legal, dan penambangan adalah illegal. Praktik geowisata, terutama kegiatan ekskursi lapangan, terkadang sengaja dipraktikkan persis dalam area penambangan. Terjadilah hukuman itu: para pelaku geowisata yang menatap aktivitas penambang dengan ekspresi dan gesture yang merepresentasikan ketidaksukaan, dan penambang yang salah tingkah dan menghentikan sementara kegiatan penambangannya. Terkadang pihak BIKK-LIPI sengaja meminta wisatawan berhenti dan lalu digelar diskusi kecil menyangkut nilai ilmiah geologis yang ada di area penambangan tersebut beserta dampak negatif dari kerusakan yang ditimbulkan dari aktivitas ilegal tersebut.

Malah dapat ditafsirkan, dalam konteks tertentu praktik geowisata 
merupakan representasi dari operasi kekerasan simbolik yang dilakukan BIKK walaupun para aktornya tidak melakukannya secara sadar. Seperti diutarakan Bourdieu bahwa pada dasarnya modal merupakan basis dominasi, walaupun tidak diakui dan disadari partisipan/aktor (Bourdieu, 1990). Dengan memiliki modal simbolis yang sangat strategis, BIKK dan aparatusnya memiliki kuasa untuk melakukan kekerasan simbolis. Inilah yang melahirkan konsep baru yang peneliti sebut sebagai kekerasan berbasis pariwisata.

Kekerasan berbasis pariwisata merupakan efek dari massifikasi kuasa modal simbolik yang beroperasi dalam ranah pariwisata yang direproduksi oleh aktor dominan yang memiliki jenis modal tersebut. Dalam konteks Karangsambung, kekerasan ini terjadi ketika aktor dominan dalam pariwisata yaitu BIKK-LIPI yang sering disebut warga dengan sebutan "kampus", mempraktikkan geowisata secara eksklusif dan mengambil route yang beririsan dengan aktivitas keseharian masyarakat lokal.

Dari kacamata masyarakat lokal, yang tampak adalah sebuah karnaval, ketika para "wong liya" (Bahasa Jawa: orang lain), yaitu pihak "kampus" dan wisatawan melakukan praktik geowisata seperti: menyaksikan film kebumian, menikmati presentasi populer kawasan geologi Karangsambung, melihat koleksi berbagai batuan di museum, mengunjungi bengkel cinderamata, dan terutama pada aktivitas ini: ekskursi lapangan di sekitar kampus dan sungai Luk Ulo. Lalu terjadi apa yang diistilahkan Foucault sebagai pendisiplinan tubuh bagi masyarakat lokal, yang harus selalu menyesuaikan diri ketika praktik geowisata berlangsung. Dan ketika ekskursi lapangan dilakukan, yang terjadi adalah fungsi laten dari praktik geowisata: pengawasan dan penghukuman terhadap para penambang. Dalam konteks ini, geowisata sebagai sebuah sistem, meminjam istilah Michel Foucault, merupakan sebuah panopticon, sebuah instrumen pengawas (Hardiyanta, 1997).

Faktanya lagi, upaya penghukuman tersebut ternyata tidak efektif dan cenderung mereproduksi perlawanan. Memang tidak bersifat langsung dan terbuka dalam artian kontak fisik, tetapi dengan simbol pula. Bentuk perlawanan ini umumnya dikreasi oleh mereka yang terhegemoni (Scott, 2000). Dan simbol perlawanan itu adalah dengan menghadirkan alat berat (beko) sebagai instrumen penambangan. Tentu saja ini merupakan pukulan telak bagi BIKK-LIPI, dan dalam konteks lebih luas juga bagi masyarakat lokal dan pemerintah daerah.

Dalam konteks inilah diperlukan struktur bersama, sebuah struktur yang mempertemukan / dualitas antara kepentingan ilmiah konservasif dan ekonomis eksploitatif. Berdasarkan penggalian aspirasi yang dilakukan ketika wawancara dengan narasumber, semua sepakat bahwa dualitas itu adalah pariwisata. Pariwisata yang diperlukan, sebagai sebuah struktur yang 


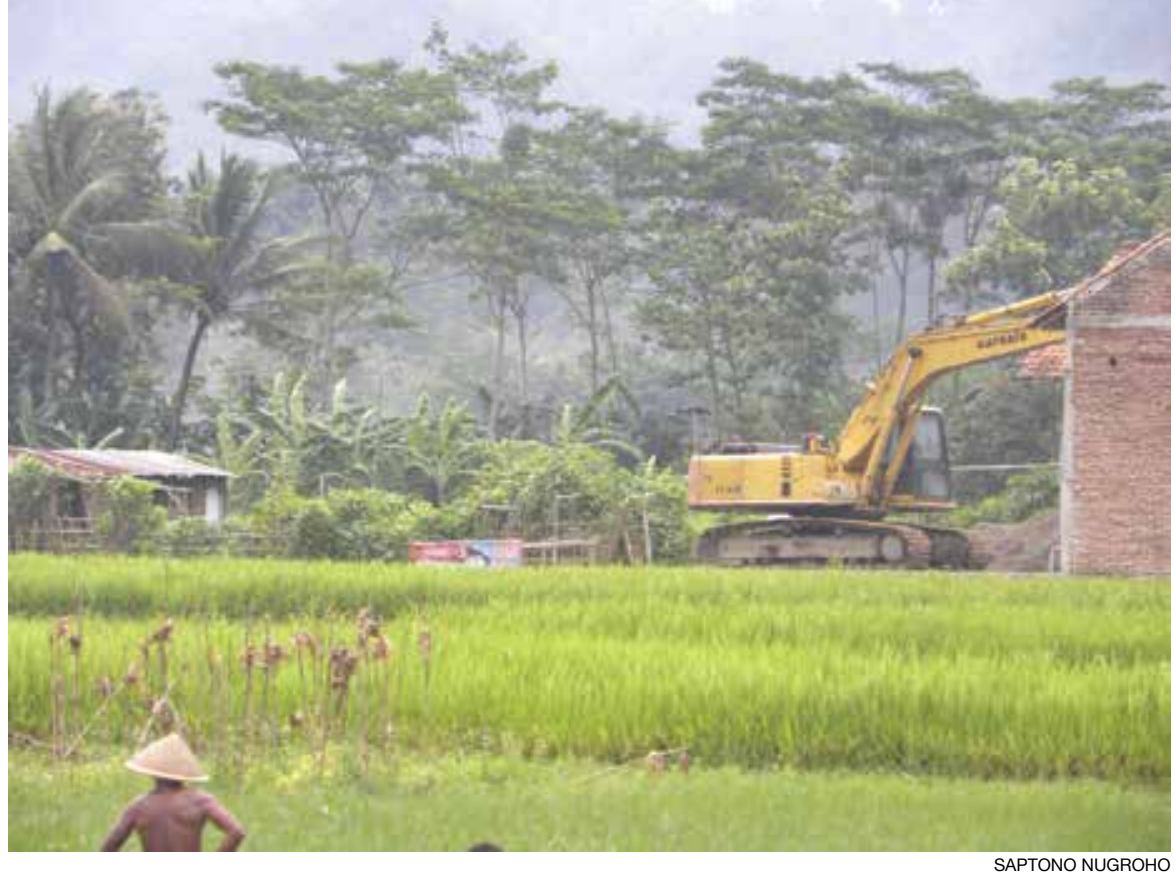

Foto 5. Alat berat Beko yang digunakan oleh penambang mesin, merupakan simbol nyata dari beroperasinya cara pandang dualisme pada level relasi manusia-alam di ranah KCAGK.

mengatasi dualisme baik di level sosial maupun alam.

\subsection{Memutus Mata Rantai Dualisme dalam Ranah: Strategi Panginyongan.}

Panginyongan merupakan istilah yang digunakan masyarakat lokal Karangsambung guna mengidentifikasi seseorang yang telah dianggap masuk sebagai bagian dari komunitas mereka, dengan terbangunnya nuansa in group feeling. Ketika seseorang dianggap telah menjadi bagian dari mereka akan disebut sebagai "wonge dhewek" (Bahasa Jawa: orang kita), sebagai lawan dari istilah "wong liya" (orang lain, the others / liyan). Indikator dari telah diterimanya seseorang menjadi bagian dari mereka ketika operasi bahasa yang digunakan dalam perbincangan adalah ngapak (logat khas Banyumasan) dan cablaka (terus terang, apa adanya, tanpa tedeng aling-aling).

Konsep panginyongan jika dikembangkan lebih luas lagi bisa dioperasikan sebagai sarana interaksi manusia dengan alamnya. Artinya, tidak hanya terbatas digunakan dalam interaksi interpersonal secara sosial, tetapi juga sebagai sarana interaksi dengan alam. Karakter egalitarian yang terkandung dalam konsep panginyongan, yaitu menerabas batasan strata sosial sehingga tercipta kesetaraan dalam berinteraksi antar aktor, dapat diterapkan ketika berhubungan dengan alam.

Strategi yang diperlukan adalah dengan melakukan apa yang disebut Giddens dengan istilah derutinisasi. Diperlukan refleksivitas oleh aktor dan kelas untuk melakukan "penjarakkan" dari rutinitas yang dilakukan. 
Derutinisasi dan refleksivitas menjadi dua kata kunci untuk melakukan kritik terhadap struktur yang sedang beroperasi di dalam ranah. Artinya, diperlukan kesadaran kolektif para aktor bahwa struktur yang ada sudah tidak memadai atau sudah usang, tidak bisa mewadahi aspirasi bersama. Fakta bahwa terjadi praktik geowisata yang tidak inklusif, dan semakin rusaknya alam karena aktivitas penambangan yang tidak terukur sedikit banyak telah menggelisahkan aktor yang ada di Karangsambung.

Dengan masifikasi gerakan untuk melakukan derutinisasi dengan melakukan refleksivitas (penjarakkan) terhadap aktivitas keseharian, pada ujungnya akan mempertanyakan struktur yang selama ini menjadi panduan dalam para aktor bertindak dalam ranah, apakah masih relevan? Dalam konteks struktur pariwisata Karangsambung, berdasarkan fakta yang ada, dipandang sudah tidak representatif lagi.

Lalu, berangkat dari pemikiran Bourdieu, diperlukan upaya mengeliminir dan meminimalisasi kekerasan simbolik yang terjadi di ranah karangsambung. Kekerasan simbolik yang muncul ketika aktivitas para aktor dilangsungkan bisa ditekan dengan mengurangi cara-cara yang kontraproduktif dalam relasi antar aktor. Artinya adalah saling menahan diri diantara mereka untuk saling menunjukkan kuasa di dalam ranah.

Berikutnya, yang diperlukan adalah instrumen empati sebagai alat baru dalam membingkai relasi antar aktor dalam ranah dan juga aktor dengan alam. Inspirasi ini berangkat dari gagasan Ponty tentang inkorporealitas (dalam Carman, 2008) yang memberikan landasan ontologis dan epistemologis menyangkut relasi manusia dengan alam. Dalam penelitian ini, rekonstruksi terhadap gagasan ketiga pemikir tersebut ternyata bisa ditemukan di konsep panginyongan. Berikut skematitasi yang ditawarkan:

Tabel 4.6. Skematisasi Panginyongan

Giddens

- Derutinisasi

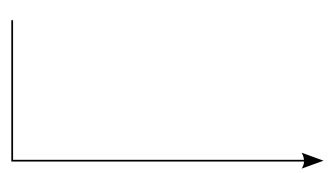

STRUKTUR PAFHWISATA BARU

Bourdieu

- Minimalisasi kekerasan simbolik

PANGINJONGAN

Sumber: Analisis data, 2014
Ponty

- Inkorporealitas

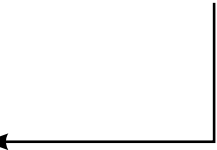

Seperti apa yang dipraktekkan oleh penambang manual (pengirig) ketika melakukan interweave dengan sungai tempat mereka mencari pasir, sejatinya adalah praktik panginyongan. Dengan menganggap Sungai Luk Ulo sebagai bagian dari dirinya, ketika tubuh mereka saling berinteraksi 
dengan mengirim sinyal komunikasi secara resiprokal, mengandaikan relasi kesetaraan. Pengirig tahu tempat pasir terkumpul dengan menjejakkan kaki mereka ke sungai yang akan mengirim suara khas ketika kaki mereka menyentuh pasir yang ada di dalam sungai. Ketika penambangan dilakukan, pengirig akan tahu kapan saatnya untuk berhenti, ketika alat pengeruk pasir yang mereka gunakan terantuk wadas (lempung padat) yang ada di dasar sungai, lagi-lagi dengan suara khas hasil benturan yang terjadi. Sebuah habitus ekofenomenologis, suatu inkorporealitas dalam balutan egalitarian.

Operasi panginyongan dapat digunakan BIKK-LIPI dan Penambang Mesin untuk lepas dari jebakan dualisme cartesian yang hinggap di habitus mereka: ekosentrisme dan antroposentrisme. Panginyongan dapat dioperasikan sebagai instrumen derutinisasi dan minimalisasi kekerasan simbolik oleh kedua kelompok aktor ini.

Ada satu aktivitas budaya yang bisa dimanfaatkan jika BIKK ingin masuk sebagai panginyongan. Ada aktivitas pengajian yang rutin diselenggarakan di tiap Rukun Tetangga (RT) setiap malam Jumat yang disebut sebagai yasinan. Forum ini berlangsung secara bergilir di tiap Kepala Keluarga (KK) yang ada dalam suatu RT, dan kegiatannya tidak melulu membaca Surat Yasin, biasanya dipenghujung acara ditutup dengan makan bersama sambil membahas isu yang sedang berkembang di desa. Forum ini sebenarnya lebih efektif jika dijadikan ruang bagi penyelesaian masalah bersama, karena penambang mesinpun berpartisipasi, sehingga dalam forum yang relatif cair ini dapat dibahas hal-hal yang sensitif seperti aktivitas menambang yang mereka lakukan. Cair, informal, dan cablaka yang merupakan karakter forum yasinan sesungguhnya merupakan kontainer bagi beroperasinya kultur panginyongan.

\section{Simpulan}

Praktik Geowisata Karangsambung saat ini lebih ditekankan sebagai suatu kegiatan untuk melandasi pemahaman proses-proses kebumian baik proses yang berlangsung jutaan tahun lalu, proses yang terjadi sekarang maupun kemungkinan proses yang terjadi pada masa-masa mendatang. Melalui kegiatan geowisata di Karangsambung, wisatawan mendapatkan gambaran aneka jenis batuan, proses pembentukan bentang alam, serta dinamika bumi.

Terkait dengan proses terjadinya praktik geowisata di Karangsambung diperoleh hasil penelitian ternyata geowisata memiliki dua makna: pertama, sebagai aktivitas wisata, merupakan tindakan para aktor kongkret yang bisa diindera secara empiris, dan kedua, sebagai sebuah strukturasi yang merupakan kegiatan teratur, sistematis, berulang dan terpola yang diproduksi oleh BIKK Karangsambung.

Berikutnya, terkait posisi agen/aktor dalam relasinya dengan alam 
Karangsambung, terdapat empat agen/ aktor umum, terkait dengan konteks relasinya dengan alam berdasarkan tafsir dan aktivitas yang dilakukan, yaitu: BIKK-LIPI, Penambang, Masyarakat Lokal, dan Pemerintah Daerah. Dari keempat aktor yang diidentifikasi tersebut, terdapat dua aktor utama yang memiliki peran penting dalam dinamika praktek geowisata di KCAGK, yaitu BIKK-LIPI dan Penambang (Mesin dan Manual).

Dalam relasinya dengan alam, BIKK-LIPI dan Penambang Mesin terperangkap pada dualisme cartesian, yang berpusat pada subyek manusia dengan rasio yang dimilikinya sehingga memandang alam sebagai obyek. Habitus yang dimiliki BIKK-LIPI adalah ekosentrisme dan Penambang Mesin memiliki habitus antroposentrisme. Menariknya, ternyata Penambang Manual (pengirig) memiliki kesadaran yang telah melampaui jebakan dualisme tersebut, dengan memiliki habitus ekofenomenologi. Jenis kesadaran ini tidak berangkat dari rasio sebagai instalasi sentral dalam berhubungan dengan alam, tetapi incorporealitas, dengan menggunakan tubuh sebagai sarana interaksi.

Lalu, implikasi bagi praktik pariwisata di Karangsambung, berdasarkan temuan yang didapat, struktur pariwisata yang ada di KCAGK masih terjebak dalam perangkap dualisme. Dualisme yang terjadi berada di aras praktik geowisata dan di tingkatan relasi yang dibangun antara manusia dengan alam. Praktik geowisata yang dikelola BIKK secara eksklusif justru menjadi sarana bagi berlangsungnya kekerasan simbolik terhadap warga. Aktivitas wisata yang berlangsung bagaikan berada dalam akuarium, menjadi tontonan bagi masyarakat lokal Karangsambung. Dalam konteks relasi para aktor dengan alamnya, secara general bisa dikatakan masih terjadi hubungan saling menguasai, dominatif, yang membelenggu dan menjebak pada relasi subyek-obyek.

\section{Saran}

Strategi panginyongan bisa dioperasikan sebagai instrumen guna mengatasi dualism trap yang terjadi, sebagai ikhtiar derutinisasi oleh para aktor. Panginyongan merupakan tindak lanjut dari reflexive monitoring of conduct ketika para aktor ingin mendekonstruksi struktur yang dirasa sudah usang dan tidak memadai lagi bagi wadah aspirasi mereka. Ketika strategi ini diterapkan, akan muncul sikap saling percaya (trust) karena mereka akan melebur sebagai "wonge dhewek" (orang kita-in group feeling) bukan sebagai "wong liya" (orang lain-outsiders) yang saling me-liyan-kan. Hal inilah yang seyogyanya diperhatikan pemangku kepentingan (para aktor umum) yang ada di Karangsambung.

Sejatinya, apa yang sudah diupayakan BIKK-LIPI dengan memfasilitasi aktivitas geowisata di KCAGK patut diapresiasi, karena merupakan upaya cerdas untuk mensosialisasikan salah satu kawasan situs geologi 
terlengkap di Asia Pasifik ini. Apalagi kegiatan ini di luar tugas pokok dan fungsi mereka, artinya, menambah kegiatan lain yang membutuhkan alokasi waktu dan tenaga. Ke depan, praktik geowisata idealnya melibatkan partisipasi masyarakat lokal dengan pilihan strategi panginyongan, untuk melatih habitus bersama, guna menghindari kegagapan (hysteresis) dalam struktur pariwisata baru yang diidealkan. Belajar dari pengirig, yang sudah menggunakan instalasi tubuhnya dalam interweave dengan alam, kiranya habitus ekofenomenologis cukup memadai dalam upaya membangun dualitas di KCAGK. Sedangkan, penambang(an) mesin harus menjadi musuh pertama, bersama, dan utama, karena merekalah sesungguhnya "wong liya" itu.

\section{Ucapan Terima Kasih}

Penulis menghaturkan terima kasih kepada seluruh pihak yang telah berkontribusi sehingga karya ini mengada: Prof. Dr. I Nyoman Darma Putra, M.Litt selaku Ketua Program Studi S2 Kajian Pariwisata Unud, Dr. Ir. Syamsul Alam Paturusi, MSP selaku Sekretaris Program S2 Kajian Pariwisata Unud dan sekaligus selaku Dewan Redaksi JUMPA. Beliau berdua telah memberikan masukan berharga dalam proses penulisan ini. Serta, para narasumber di Karangsambung, yang telah banyak membantu dalam memberikan data.

\section{Daftar Pustaka}

Alwasilah, A Chaedar. 2002. Pokoknya Kualitatif: Dasar-dasar Merancang dan Melakukan Penelitian Kualitatif. Jakarta: Pustaka Jaya.

Ansori, Chusni. 2012. Panduan Geowisata, Artefak dan Singkapan Geologi pada Rangkaian Peg. Serayu dan Selatan Jawa, Kebumen: UPT Balai Informasi dan Konservasi Kebumian Karangsambung

Bourdieu, Pierre. 1990. The Logic Of Practise, (Translated by Nice, Richard). California: Stanford University Press

Carman, Taylor. 2008. Merleau-Ponty. Oxon: Routledge

Dowling, Ross K dan David Newsome. 2006. Geotourism. Oxford: ButterworthHeinemann

Giddens, Anthony. 1984. The Constitution of Society: Outline of the Theory of Structuration. Berkeley and Los Angeles: University of California Press

Hardiyanta, Petrus Sunu. 1997. Michel Foucault Displin Tubuh. Yogyakarta: LkiS

Harker, Richard dkk. 2009. Habitus X Modal + Ranah=Praktek, Pengantar Paling Komprehensif Kepada Pemikiran Piere Bourdieu. Yogyakarta: Jala Sutra

Kusumahbrata, Yunus. 2008. Geoheritage of Indonesia (in Geoheritage of East and Southeast Asia), Kuala Lumpur: Ampang Press SDN. BHD

Scott, James C. 2000. Senjatanya Orang-orang yang Kalah: Bentuk-bentuk perlawanan sehari-hari kaum tani. Jakarta: Yayasan Obor Indonesia 
Priyono, Harry B. 2002. Anthony Giddens: Suatu Pengantar. Jakarta: Gramedia Putri, LG. Saraswati. 2013. Relasi Manusia dan Alam, Perspektif Ekofenomenologi. Depok: Disertasi Doktor Fakultas Ilmu Budaya Universitas Indonesia. Ritzer, Geroge. 2013. Sosiologi. Yogyakarta: Pustaka Pelajar

\section{Profil Penulis}

Saptono Nugroho lahir di Jakarta tanggal 20 September 1976, menempuh jenjang S1 Sosiologi di Fakultas Ilmu Sosial dan Ilmu Politik Universitas Jenderal Soedirman Purwokerto, dan S2 di Kajian Pariwisata Universitas Udayana Bali. Saat ini mengabdi sebagai pengajar di Fakultas Pariwisata Universitas Udayana, mengampu mata kuliah Filsafat Ilmu Pariwisata dan Sosiologi Pariwisata. 